\title{
Effects of di-iso-butyl phthalate on testes of prepubertal rats and mice
}

\author{
By
Xiao Bo ZHU, Tat Wei TAY, Bibin Bintang ANDRIANA, Mohammad Shah ALAM, Ehn Kyoung CHOI, Naoki TSUNEKAWA, Yoshiakira KANAI, \\ and Masamichi KUROHMARU*
}

Department of Veterinary Anatomy, Graduate School of Agricultural and Life Sciences, The University of Tokyo, 1-1-1 Yayoi, Bunkyo-ku, Tokyo, 113-8657, Japan

-Received for Publication, November 24, 2009-

\begin{abstract}
Key Words: Di-iso-butyl phthalate (DiBP), Mice, Prepubertal stage, Rats, Spermatogenic cell apoptosis
Summary: Di-iso-butyl phthalate (DiBP), a special plasticizer, is used as a substitute for di(n-butyl) phthalate(DBP). The effects of DiBP on testes in prepubertal rodents still remain to be obscure. Testicular toxicity of DiBP was investigated in 21-day-old Sprague-Dawley rats and C57BL/6N mice, using with in situ TUNEL method. For an acute exposure experiment, animals were once given DiBP at various concentrations by oral gavage. For a subchronic exposure experiment, they were daily given DiBP at various concentrations for consecutive 7 days. Controls were treated with corn oil under the same condition. For a recovery experiment, rats were once given DiBP $(1000 \mathrm{mg} / \mathrm{kg})$, and were sacrificed at day 1 to 8 after administration. Furthermore, the disorder of vimentin filaments in Sertoli cells after daily administration of DiBP (500 $\mathrm{mg} / \mathrm{kg}$ ) for consecutive 7 days in rats also identified by immunohistochemistry using anti-vimentin antibody. As a result, the present study demonstrated that DiBP can induce testicular atrophy in rats due to the increase of TUNEL-positive spermatogenic cells in both acute and subchronic exposure experiments. At the same time, the disorder of vimentin filaments in Sertoli cells was recognized. However, no such damages could be found in mouse testis. For the recovery experiment, the testis weight and testicular morphology returned to normal at day 6 after administration. In conclusion, the present study indicates that DiBP causes the significant increase of TUNEL-positive spermatogenic cells and the disorder of vimentin filaments in Sertoli cells in rats and that DiBP shows a species-specific toxicity.
\end{abstract}

\section{Introduction}

Phthalate esters, widely used as a plasticizer in the manufacturing process of consumer products, are known to impair spermatogenesis at postnatal stage and disturb the development of male reproductive system at fetal stage in rodents. For example, administration of di-butyl phthalate (DBP) to male rats induced cryptorchidism, hypospadias, abnormal Leydig cell aggregation, multinucleated gonocytes, and decreased testicular testosterone level at fetal stage ${ }^{1-8)}$ and induced infertility at adult ${ }^{9,}{ }^{10}$. Testicular atrophy, reduction of testicular mRNA expression of steroidogenesis related genes, and infertility have been induced by oral administration of di(2-ethylhexyl) phthalate (DEHP) in prepubertal male rats ${ }^{1-13)}$, and testicular damage caused by DEHP showed age-specific in rats $^{14)}$. Furthermore, mono(2-ethylhexyl)phthalate
(MEHP), a monoester metabolic product of DEHP, also induced the disorder of testicular structures due to cell death and sloughing of spermatogenic cells in prepubertal laboratory animals ${ }^{11,15-19)}$. Phthalate esters including DiBP are rapidly hydrolyzed to monoester by hepatic and intestinal non-specific hydrolases in a variety of animal species $^{20)}$. It has been speculated that the different effects of each phthalate ester among each animal species have a relationship with the structure of the butyl moiety in the side chain of phthalate monoesters ${ }^{21}$. Di-iso-butyl phthalate (DiBP) $\left[\mathrm{C}_{16} \mathrm{H}_{22} \mathrm{O}_{4}-\mathrm{C}_{6} \mathrm{H}_{4} \mathrm{CO}_{2} \mathrm{CH}_{2} \mathrm{CH}\left(\mathrm{CH}_{3}\right)_{22}\right]$ has similar application properties to DBP and is substituted for DBP. Thus, DiBP has been used in polyvinyl chloride (PVC), inks, paints, adhesives and cosmetics ${ }^{22}$. Although DiBP has been frequently used, for example, 100 tons per year in Denmark ${ }^{23)}$, only a few reports on the effects of $\mathrm{DiBP}$ on male reproductive system are available at pres-

Corresponding author: M. Kurohmaru, Department of Veterinary Anatomy, Graduate School of Agricultural and Life Sciences, The University of Tokyo, 1-1-1 Yayoi, Bunkyo-ku, Tokyo, 113-8657, Japan. E-mail: amkuroh@mail.ecc.u-tokyo.ac.jp

This work was supported in part by Grants-in-Aid from the Ministry of Education, Culture, Sports, Science and Technology of Japan. 
ent. Oishi and Hiraga (1980a) demonstrated that DiBP reduced body weight and Zinc concentration in young mouse testes by feeding a diet containing 2\% DiBP. Furthermore, skeletal malformations, undescended testes, reduced anogenital distance and testicular histopathological effects were observed by administration of DiBP in rats at fetal stage ${ }^{23,24)}$. Therefore, in order to clarify the effects of DiBP on testes in detail, the present study was carried out using prepubertal rats and mice, especially focusing on apoptotic spermatogenic cells.

\section{Material and Methods}

Test compounds: DiBP, di-iso-butyl phthalate standard, CAS No,84-69-5, purity 99.9\%, and corn oil were obtained from Wako Pure Chemical Industries, Ltd. (Osaka, Japan).

Animals and concentrations of DiBP: Twenty-oneday-old Sprague-Dawley (SD) male rats and C57B1/6N male mice were purchased from Charles River, Co., Japan. For an acute exposure experiment, they were once given DiBP at various concentrations $(100,300,500$, 800 , or $1,000 \mathrm{mg} / \mathrm{kg}$ ) in corn oil by oral gavage, and 1 day later, the animals were sacrificed under anesthesia by diethyl ether. For a subchronic exposure experiment, they were daily given $\mathrm{DiBP}$ at various concentrations (100, $300,500,800$, or $1,000 \mathrm{mg} / \mathrm{kg}$ ) for consecutive 7 days in corn oil by oral gavage, and 1 day later (after the last administration), they were sacrificed as well. For a recovery experiment, SD male rats were once given $\operatorname{DiBP}(1,000$ $\mathrm{mg} / \mathrm{kg}$ ), and were sacrificed at 1 day (D1) to D8 after administration. The concentrations of each experiment were based on the findings of several previous studies on MEHP and $\mathrm{DBP}^{11,17,25}$. Animals were given DiBP in corn oil at a volume equal to $4 \mathrm{ml} / \mathrm{kg}$. Control groups were received the same volume of corn oil. Then, the testes in each experiment were excised and fixed in $4 \%$ paraformaldehyde (PFA) in $0.01 \mathrm{M}$ phosphate buffered saline (PBS) at $4{ }^{\circ} \mathrm{C}$. Thereafter, they were dehydrated in ethanol, cleared in xylene, and embedded in paraffin. Paraffin blocks were cut at $5 \mu \mathrm{m}$ in thickness.

All procedures were carried out in accordance with a protocol approved by the Animal Care and Use Committee of the Graduate School of Agricultural and Life Sciences, The University of Tokyo.

In situ TUNEL method: Apoptosis of spermatogenic cells was examined using the TUNEL method according to the protocol of the 'in situ apoptosis detection kit' (TaKaRa, Tokyo, Japan). The sections were deparaffinized, rehydrated, and then predigested with $10 \mu \mathrm{g} / \mathrm{ml}$ protease $\mathrm{K}$ for $15 \mathrm{~min}$. Thereafter, they were incubated in PBS containing $3 \% \mathrm{H}_{2} \mathrm{O}_{2}$ for $15-30$ min to block endogenous peroxidase activity. Then, they were incubated with a fluorescein isothiocyanate (FITC)-labeled TdT enzyme in a humidified chamber at $37^{\circ} \mathrm{C}$ for $90 \mathrm{~min}$. After washing, the sections were incubated with antiFITC horseradish peroxidase (HRP) conjugate at $37^{\circ} \mathrm{C}$ for $30 \mathrm{~min}$. Finally, TUNEL-positive cells were detected by 3,3'-diaminobenzidine tetrahydrochloride (DAB) (Wako, Tokyo, Japan) substrate, counterstained with methyl green dye, mounted, and observed using an optical microscope for counting the apoptotic cell number per each seminiferous tubule.

Immunohistochemistry: Rats were daily given DiBP $(500 \mathrm{mg} / \mathrm{kg}$ ) for consecutive 7 days, and sacrificed. Thereafter, testes were excised, fixed, and embedded in paraffin, as above mentioned. For vimentin immunohistochemistry, paraffin sections were deparaffinized, rehydrated, and later heated in $0.01 \mathrm{M}$ citrate buffer (pH 6.0) for $10 \mathrm{~min}$ in a microwave to facilitate antigen retrieval. Then, they were treated with 3\% peroxidase for $30 \mathrm{~min}$ to eliminate endogenous peroxidase and blocked with a TNB blocking buffer. A monoclonal anti-vimentin antibody (mouse immunoglobulin $\mathrm{M}$ [IgM] isotype, clone LN-6; Sigma, St. Louis, MO, USA) at a dilution 1:100 was used for staining vimentin in seminiferous tubules. The sections were fixed in 4\% PFA for $24 \mathrm{hr}$, rinsed in PBS, blocked with a TNB $(0.1 \mathrm{M}$ Tris-HCl, $0.15 \mathrm{M} \mathrm{NaCl}, 0.5 \%$ Blocking Reagent, $\mathrm{pH}$ 7.5) blocking buffer, supplied in TSA (Tyramide Signal Amplification) Biotin System kit (Perkin Elmer Life Sciences, Boston, MA, USA), and incubated with primary antibody at $4^{\circ} \mathrm{C}$ overnight. Thereafter, they were incubated with biotinylated goat anti-mouse IgG secondary antibody for $1 \mathrm{hr}$ at room temperature, followed by the $\mathrm{ABC}$ kit (Funakoshi, Tokyo, Japan). The immunoreactions were visualized with $0.05 \% \mathrm{DAB}$ (Wako) with $\mathrm{H}_{2} \mathrm{O}_{2}$ in PBS. The sections were counterstained with methyl green dye, and observed by light microscopy.

Statistical analysis: Only intact and round seminiferous tubules were selected for counting. The number of TUNEL-positive cells was counted in 15-20 randomlyselected round seminiferous tubules from each animal of all control and treated groups. The data, calculated as a percentage of total, are expressed as mean \pm S.E.M. Statistical analysis was conducted using the Student's paired $t$-test. The $p$-values less than 0.05 were considered statistically significant. Asterisks indicate a statistically significant difference compared to the control, ${ }^{*} p<0.05$, ${ }^{* *} p<0.01,{ }^{* * *} p<0.001$.

\section{Results}

Acute exposure experiment: In the acute experiment, the administration of DiBP did not significantly reduce the testis weight at any concentrations in rats (Fig. 1a). Similarly, no significant reduction of the testis weight also occurred in mice (Fig. 1c). In rats, the number of TUNEL-positive spermatogenic cells showed a signifi- 

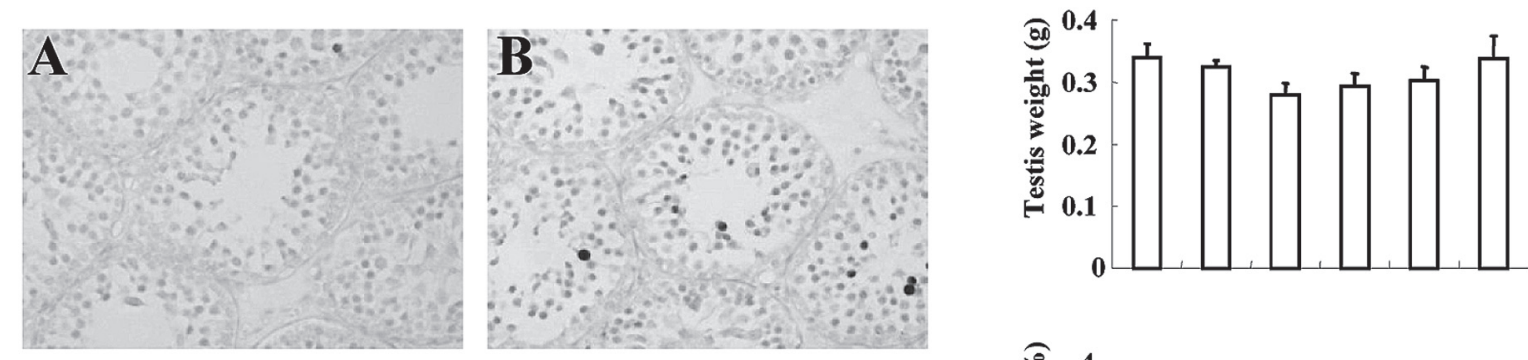

a
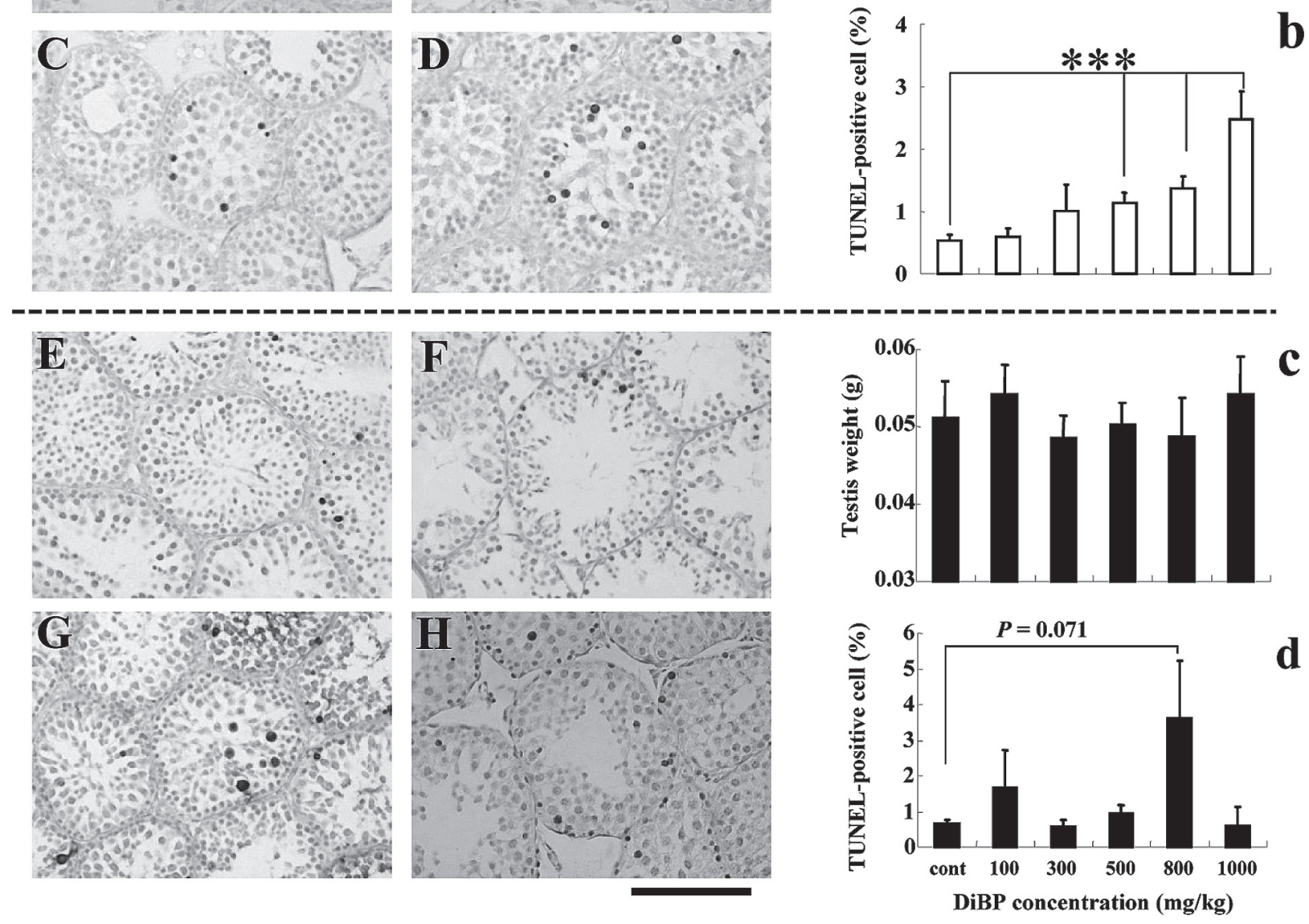

Fig. 1. Acute exposure experiment. Changes in testis weight $(a, c)$ and TUNEL-positive cells in testes of rats $(A-D, b)$ and mice (E-H, d) after DiBP administration. Animals exposed to 0 (A, E), 500 (B, F), $800(\mathrm{C}, \mathrm{G})$, or 1,000 mg/kg (D, H) of DiBP. Testis weight did not reduce in both mice and rats $(\mathrm{a}, \mathrm{c})$ after DiBP administration. Ratio of TUNEL-positive cells increased $(p<0.001)$ in the DiBP treated rats $(\mathrm{B}, \mathrm{C}, \mathrm{D}, \mathrm{b})$ at higher $(\geq 500 \mathrm{mg} / \mathrm{kg})$ concentrations. Mice showed a tendency to increase $(p=0.071)$ apoptotic spermatogenic cells $(\mathrm{G}, \mathrm{d})$ only in the $800 \mathrm{mg} / \mathrm{kg}$ DiBP treated group. Data represent means \pm S.E. bar $=100 \mu \mathrm{m}$.

cant increase at $24 \mathrm{hr}$ in the 500,800 , and $1,000 \mathrm{mg} / \mathrm{kg}$ $(p<0.001)$ DiBP treated groups, compared to the control (Fig. 1B, C, D, b). As shown in Fig. 1b, it increased in a dose-dependent manner. However, in mice, TUNELpositive cells increased only in the $800 \mathrm{mg} / \mathrm{kg} \operatorname{DiBP}(p=$ 0.071) treated group (Fig. 1G, d).

Subchronic exposure experiment: In the subchronic experiment, the animals were daily given DiBP of each concentration for consecutive 7 days. In rats, a significant loss of the testis weight was found $(p<0.001)$ in the 500,800 , and $1,000 \mathrm{mg} / \mathrm{kg} /$ day treated groups, compared to the control (Fig. 2a), whereas in mice, only the $1,000 \mathrm{mg} / \mathrm{kg} /$ day treated group revealed a significant reduction $(p<0.01)$ (Fig. 2c). The number of TUNELpositive spermatogenic cells in rats were significantly ( $p$ $<0.05$ ) increased in the 500,800 , and $1,000 \mathrm{mg} / \mathrm{kg} /$ day DiBP treated groups, compared to the control (Fig. 2B, $\mathrm{C}, \mathrm{D}, \mathrm{b}$ ), but not in the 100 and $300 \mathrm{mg} / \mathrm{kg} /$ day treated groups. In mice, no significant increase in the number of TUNEL-positive spermatogenic cells was found at any concentrations (Fig. 2d).

Recovery experiment after a single administration of DiBP: The recovery experiment was carried out in rats. Although the testis weight showed no significant loss at 

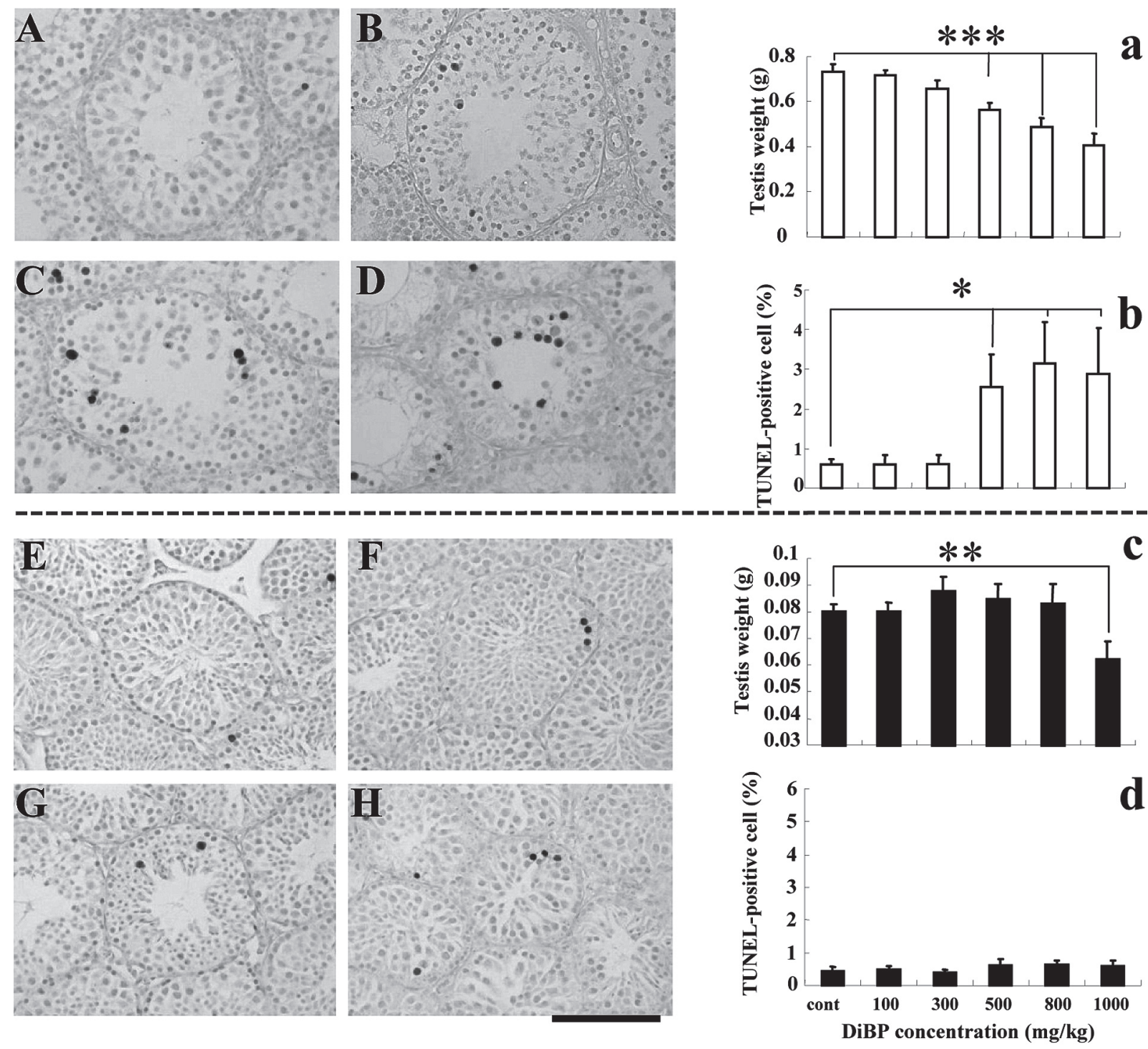

Fig. 2. Subchronic exposure experiment. Changes in testis weight (a, c) and TUNEL-positive cells in testes of rats (A-D, b) and mice (E-H, d) after DiBP administration for consecutive 7 days. Animals exposed to 0 (A, E), 500 (B, F), 800 (C, G), or 1,000 mg/kg/day (D, H) of DiBP. Testis weight reduced in rats in the 500,800 , and $1,000 \mathrm{mg} / \mathrm{kg}$ /day DiBP treated groups (a). Only the $1,000 \mathrm{mg} / \mathrm{kg}$ DiBP treated group showed a significant testis weight loss $(p<0.01)$ compared to the control (c). TUNEL -positive cells increased in parallel with testis weight loss in rats (b). No significant changes in the number of TUNEL-positive cells were observed in mice (d). Data represent means \pm S.E. bar $=$ $100 \mu \mathrm{m}$.

1 day (D1) after administration of $1,000 \mathrm{mg} / \mathrm{kg} \mathrm{DiBP}$, it reduced significantly at D2 $(p<0.05)$ and D5 $(p<$ $0.001)$, compared to the control. Thereafter, it recovered to normal level at D6 and D8 (Fig. 3a). TUNEL-positive spermatogenic cells still revealed an increase in number at D1, D2, and D5. While, they abruptly decreased, and became almost the same with those in the control at D6 and $\mathrm{D} 8$.

Distribution of vimentin filaments: Vimentin filaments were expressed both in the control (Fig. 4A) and $500 \mathrm{mg} / \mathrm{kg} /$ day DiBP treated rats for 7 consecutive days
(Fig. 4B). In the control, vimentin appeared obviously in the perinuclear and basal regions of Sertoli cells, and it extended towards the lumen (Fig. 4A). No TUNELpositive spermatogenic cells were detected in the seminiferous tubule of the control (Fig. 4C). In the DiBP treated rat, vimentin filaments were partly disorganized or disappeared in the perinuclear and basal regions of Sertoli cells. Sloughing of TUNEL-positive spermatocytes from the epithelium was observed in the treated group as shown in Fig. 4D. 

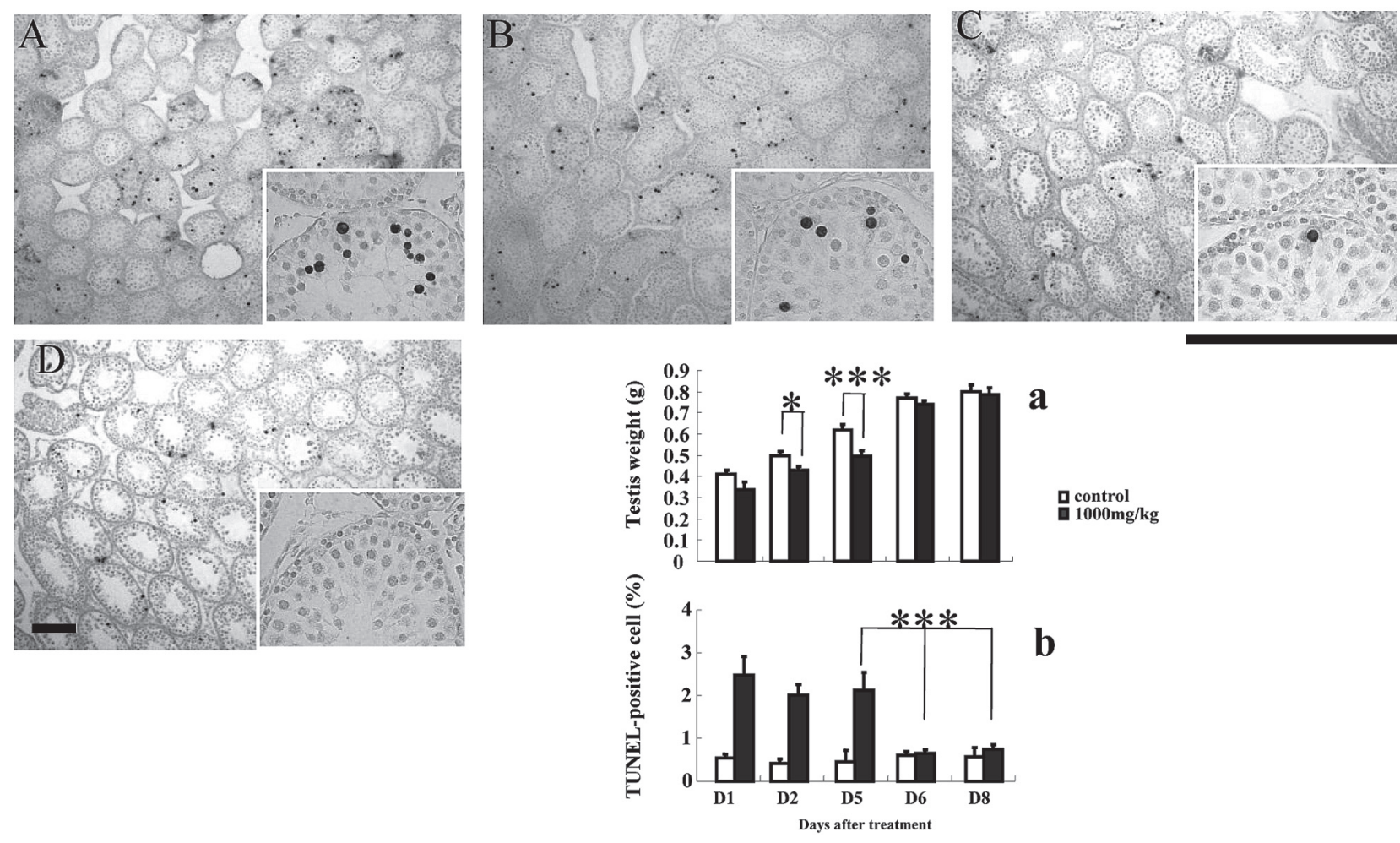

Fig. 3. Recovery experiment. Light micrographs and diagrams showing the changes in TUNEL-positive cells at D1 (A), D5 (B), D6 (C) and D8 (D) after DiBP administration in rats. Inset shows an enlarged view of each section. Comparison of the testis weight of the control and 1,000 $\mathrm{mg} / \mathrm{kg}$ DiBP treated rats from D1 to D8 (a.b). Testis weight in the treated groups was lower than that in the control group (a). A recovery $(p<0.001)$ occurred at D6 (b). Data represent means \pm S.E. bar $=100 \mu \mathrm{m}$.

\section{Discussion}

The present study illustrates that DiBP induces apoptosis in spermatogenic cells in 21-day-old rats via acute or subchronic oral administration. Since oral administration of DiBP at higher concentrations can elicit a damage in prepubertal rat testes, it is obvious that DiBP reveals a testicular toxicity, similar to other phthalate esters as previously reported ${ }^{10,23,24,26,27)}$. In contrast, a significant increase of apoptotic spermatogenic cells could not be observed in prepubertal mouse testis, even at higher concentrations and consecutive exposure for 7 days. Five-week-old rats $^{28)}$ and mice ${ }^{29)}$ exposed to $2 \%$ DiBP in diet showed a loss of testis weight only in rats. The patterns of responses to testicular oxidative stress seem to be species-specific ${ }^{30}$. Although in some previous studies, the different specificity between mice and rats was confirmed by administration of the same chemical agent ${ }^{31-33)}$, the detailed mechanism of this speciesdifference is still thought to be equivocal. Kluwe et al. (1982) elucidated that DEHP caused liver tumors in both mice and rats, but di (2-ethylhexyl) adipate (DEHA) triggered liver tumors only in mice, not in rats. In addition,
Murakami et al. (1995) showed that after administration of procymidone for 3 months, LH levels in serum, testis and pituitary were increased for 13 weeks in rats, while for 4 weeks in mice. In contrast to rats, no significant increase in testosterone occurred in mice either in vivo or ex vivo during the course of the study. They concluded that the difference between mice and rats appeared in response of Leydig cells to LH stimulation in procymidone administration. Furthermore, the difference in response to trichloroethylene (TCE, a well-known carcinogen in laboratory animals) between mice and rats is suggested to be due to the difference in matabolism ${ }^{34)}$. But, the precise mechanism involved in is not yet clearly defined ${ }^{35)}$. Our previous studies showed that MEHP, a metabolic product of DEHP, significantly induced spermatogenic cell apoptosis in both mouse and rat testes ${ }^{5,17-19)}$. Conversely, in this study, DiBP affected testes only in rats. Although the chemical structure of DiBP is similar to that of DEHP, the present study assumes that the effects of DiBP on testes are species-specific. Furthermore, the testicular response to oral administration of DEHP may be due to pharmacokinetic rather than tissue sensitivity difference ${ }^{14)}$, and even in the same species, an age-specific ${ }^{14,36}$ 

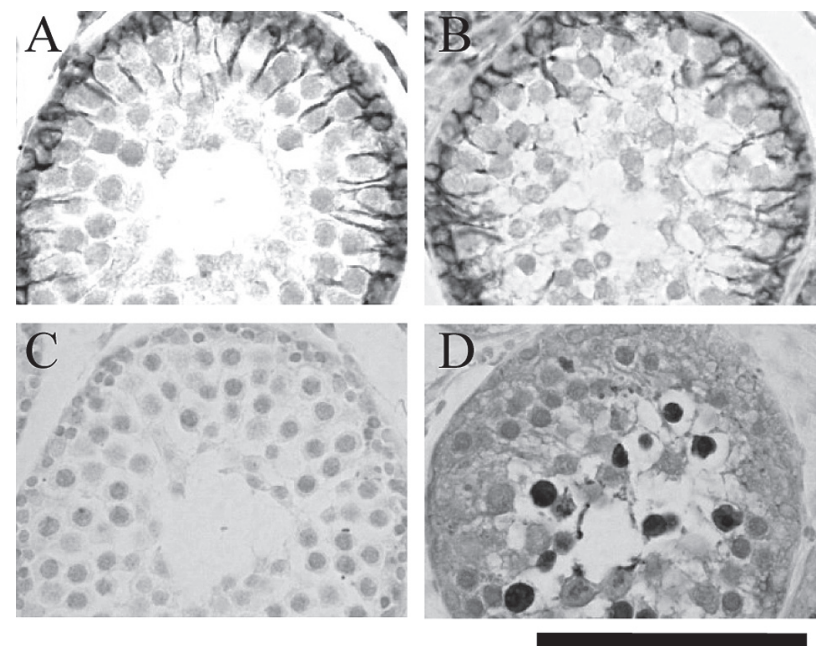

Fig. 4. Distribution of vimentin filaments in Sertoli cells and TUNELpositive cells in the control $(\mathrm{A}, \mathrm{C})$ and the DiBP treated group (B, D). Vimentin filaments were partly disorganized or disappeared in Sertoli cells. bar $=100 \mu \mathrm{m}$.

or sexual-specific ${ }^{31)}$ effect is also confirmed. Moreover, the initiation of spermatogenic cell proliferation at fetal stage is different between mice and rats ${ }^{37)}$, and the length of spermatogenic cell cycle at adult is 12.9 days in rats ${ }^{38}$ and 8.6 days in mice ${ }^{39)}$. These differences may contribute to the different results between mice and rats in the present study to some extent.

The population of TUNEL-positive spermatogenic cells reduced in a time-dependent manner in rats in the recovery experiment after a single administration of $1,000 \mathrm{mg} / \mathrm{kg}$ DiBP. The abrupt increase of TUNELpositive spermatogenic cells was observed at D1-D5, and then the significant regression occurred at D6. In the MEHP recovery experiment, TUNEL-positive cells also reduced in a time-dependent manner in 21-day-old mice, but the rate of testis weight gain was lower compared to the control from D1 to D ${ }^{18)}$. After administration, $80 \% \sim 90 \%$ of MEHP is excluded from the body within $24 \mathrm{hr}^{11,40)}$, indicating that even though MEHP is almost eliminated from the body, its effects can still persist in testes ${ }^{18)}$. By MEHP administration, the number of TUNEL-positive cells gradually decreased from D3 to D7, and reached the same amount with the control at D9. While, DiBP caused a significant loss of testis weight at D2 and D5, and then the testis weight returned to the normal level at D6, compared to the control. Similarly, the number of TUNEL-positive cells decreased and returned to the baseline as the control at D6.

To our knowledge, no data are available on the elimination time of DiBP from the body. From our previous and present data, it seems that the testicular recovery in DiBP exposure is earlier than that in MEHP exposure. In other words, the testicular toxic effects of DiBP are weaker than those of MEHP. This supports the view that MEHP triggers a sequence of disruptive events in testes, which still persists after elimination of $\mathrm{MEHP}^{11)}$, but persists not so long in DiBP.

Although the apoptotic spermatogenic cells induced by phthalate esters were detected with in situ TUNEL method. TUNEL-positive labeling was not found in Sertoli cells in rats ${ }^{41-43)}$ and mice ${ }^{17-19,44)}$. In addition, both in vivo and in vitro experiments demonstrated that the Sertoli cell is the primary site of phthalate-induced testicular toxicity ${ }^{45}$. Sertoli cell alterations, including vacuolization, inhibition of transferring secretion and etc., can induce spermatogenic cell apoptosis ${ }^{41)}$. This prompted us to focus our attention on primary effects of DiBP on Sertoli cells. Previous experiments demonstrated that MEHP causes the alternation of Sertoli cell cytoskeleton in mice and rats, particularly in distribution of vimentin filaments ${ }^{19,41)}$. This study showed that vimentin filaments were partly disorganized or disappeared in the perinuclear and basal regions of Sertoli cells in the DiBP treated rat. At the same time, sloughing of TUNELpositive spermatogenic cells from the seminiferous epithelium was observed. Since vimentin filaments of Sertoli cells play an important role in the maintenance of spermatogenesis ${ }^{46)}$, our finding suggests that consecutive exposure of DiBP can induce the conspicuous alterations in distribution of vimentin filaments, and it correlates with sloughing of spermatogenic cells from the seminiferous epithelium. From the present recovery experiment, vimentin filaments can be reorganized after elimination of DiBP, and then spermatogenic cells repopulate and are restored ${ }^{46)}$.

In conclusion, our present study showed that DiBP caused a significant increase of TUNEL-positive spermatogenic cells and a disorder of vimentin filaments in rats. These toxic effects are reversible, and testes recover to normal until day 6 after administration. We suggest that DiBP can be a lower-potent toxic agent than MEHP and reveals a species-specific toxicity.

\section{References}

1) Ema M, Miyawaki E and Kawashima K. Further evaluation of developmental toxicity of di-n-butyl phthalate following administration during late pregnancy in rats. Toxicol Lett 1998; 98:8793.

2) Ema M, Miyawaki E and Kawashima K. Critical period for adverse effects on development of reproductive system in male offspring of rats given di-n-butyl phthalate during late pregnancy. Toxicol Lett 2000; 111:271-278.

3) Mylchreest E, Cattley RC and Foster PM. Male reproductive tract malformations in rats following gestational and lactational exposure to di(n-butyl) phthalate: an antiandrogenic mechanism? Toxicol Sci 1998; 43:47-60.

4) Mylchreest E, Sar M, Cattley RC and Foster PMD. Disruption of androgen-regulated male reproductive development by di(n-butyl) phthalate during late gestation in rats is different from flutamide. 
Toxicol Appl Pharmacol 1999; 156:81-95.

5) Mylchreest E, Wallace DG, Cattley RC and Foster PMD. Dosedependent alterations in androgen-regulated male reproductive development in rats exposed to di(n-butyl) phthalate during late gestation. Toxicol Sci 2000; 55:143-151.

6) Barlow NJ and Foster PM. Pathogenesis of male reproductive tract lesions from gestation through adulthood following in utero exposure to di(n-butyl) phthalate. Toxicol Pathol 2003; 31:397410.

7) Fisher JS, Macpherson S, Marchetti N and Sharpe RM. Human 'testicular dysgenesis syndrome': a possible model using in-utero exposure of the rat to dibutyl phthalate. Hum Reprod 2003; 18: $1383-1394$.

8) Lehmann KP, Phillips S, Sar M, Foster PM and Gaido KW. Dosedependent alteraton in gene expression and testosterone synthesis in the fetal testes of male rats exposed to di (n-butyl) phthalate. Toxicol Sci 2004; 81:60-68.

9) Mahood IK, Hallmark N, Mckinnell C, Walker M, Fisher JS and Sharpe RM. Abnormal Leydig cell aggregation in the fetal testis of rats exposed to di(n-butyl) phthalate and its possible role in testicular dysgenesis. Endocrinology 2005; 146:613-623.

10) Mahood IK, Scott HM, Brown R, Hallmark N, Walker M and Sharpe RM. In utero exposure to di(n-butyl) phthalate and testicular dysgenesis: comparison of fetal and adult end points and their dose sensitivity. Environ Health Perspect 2007; 115:55-61.

11) Teirlynck O, Kaufman JM, Bogaert MG and Roels H. Testicular toxicity induced by dosing of di-and mono-(2-ethylhexyl) phthalate in the rat. Toxicol Lett 1988; 40:85-91.

12) Borch J, ladefoged $O$, Hass $U$ and Vinggaard AV. Steroidogenesis in fetal male rats is reduced by DEHP and DINP, but endocrine effects of DEHP are modulated by DEHA in fetal, prepubertal and adult male rats. Reprod Toxicol 2004; 18:53-61.

13) Borch J, Metzdorff SB, Vinggaard AM, Brokken LB and Dalgaard M. Mechanisms underlying the anti-androgenic effects of diethylhexyl phthalate in fetal rat testis. Toxicology 2006a; 223:144155.

14) Sjöberg P, Lindqvist NG and Plöen L. Age-dependent response of the rat testes to di (2-ethylhexyl) phthalate. Environ Health Perspect 1986; 65:237-242.

15) Andriana BB, Tay TW, Tachiwana T, Sato T, Ishi M, Awal MA, Kanai Y, Kurohmaru M and Hayashi Y. Effects of mono (2-ethylhexyl) phthalate (MEHP) on testes in rats in vitro. Okajimas Folia Anat Jpn 2004; 80:127-136.

16) Awal MA, Kurohmaru M, Ishiii M, Andriana BB, Kanai $Y$ and Hayashi Y. Mono-(2-ethylhexyl) phthalate (MEHP) induces spermatogenic cell apoptosis in guinea pig testes at prepubertal stage in vitro. Int J Toxicol 2005; 23:349-355.

17) Tay TW, Andriana BB, Ishii M, Choi EK, Zhu XB, Alam MS, Tsunekawa N, Kanai Y and Kurohmaru M. An ultrastructural study on the effects of mono (2-ethylhexyl) phthalate on mice testes: cell death and sloughing of spermatogenic cells. Okajimas Folia Anat. Jpn 2007a; 83:123-130.

18) Tay TW, Andriana BB, Ishii M, Choi EK, Zhu XB, Alam MS, Tsunekawa N, Kanai Y and Kurohmaru M. Phagocytosis plays an important role in clearing dead cells caused by mono (2-ethylhexyl) phthalate administration. Tissue Cell 2007b; 39:241-246.

19) Tay TW, Andriana BB, Ishii M, Tsunekawa N, Kanai $Y$ and Kurohmaru M. Disappearance of vimentin in Sertoli cells: a mono (2-ethylhexyl) phthalate effect. Int J Toxicol 2007c; 26:289-295.

20) Albro JB and Thomas RO. Enzymatic hydrolysis of di-(2-ethylhexyl) phthalate by lipases. Biochim Biophys Acta 1973; 306: 380-390.

21) Foster PMD, Lake BG, Thomas LV, Cook MW and Gangolli SD. Studies on the testicular effects and zinc excretion produced by various isomers of monobutyl-o-phthalate in the rat. Chem Biol Interact 1981; 34:233-238.

22) European Council for Plasticisers and Intermediates website,
WWW. phthalates. com

23) Borch J, Axelstad M, Vingggaard AM and Dalgaard M. Diisobutyl phthalate has comparable anti-androgenic effects to di-n-butyl phthalate in fetal rat testis. Toxicol Lett 2006b; 163:183-190.

24) Saillenfait AM, Sabaté JP and Gallissot F. Developmental toxic effects of diisobutyl phthalate, the methyl-branched analogue of di-n-butyl phthalate administration by gavage to rats. Toxicol Lett 2006; 165:39-46.

25) Ryu JY, Lee BM, Kacew S and Kim HS. Identification of differentially expressed ganes in the testis of Sprague-Dawley rats treated with di(n-butyl) phthalate. Toxicology 2007; 234:103112.

26) Harris CA, Henttu P, Parker MG and Sumpter JP. The estrogenic activity of phthalate ester in vitro. Environ Health Perspect 1997; 105:802-811.

27) Stroheker T, Regnier JF, Lassurguere J and Chagnon MC. Effects of in utero exposure to di-(2-ethylhexyl) phthalate: Distribution in the rat fetus and testosterone production by rat fetal testis in culture. Food Chem Toxicol 2006; 44:2064-2069.

28) Oishi S and Hiraga K. Testicular atrophy induced by phthalate acid monoester: effects of zinc and testosterone concentrations. Toxicology 1980a; 15: 197-202.

29) Oishi S and Hiraga K. Effect of phthalate acid esters on mouse testis. Toxicol Lett 1980b; 5:413-416.

30) Samanta L and Chainy GB. Response of testicular antioxidant enzymes to hexachlorocyclohexane is species specific. Asian J Androl 2002; 4:191-194.

31) Kluwe WM, McConnell EE, Huff JE, Hasemen JK, Douglas JF and Hartwell WV. Carcinogenicity testing of phthalate esters and related compounds by the national toxicology program and the national cancer institute. Environ Health Perspect 1982; 45:129133.

32) Murakami M, Hosokawa S, Yamada T, Harakawa M, Ito $M$, Koyama Y, Kimura J, Yoshitake A and Yamada H. Species-specific mechanism in rat Leydig cell tumorigenesis by procymidone. Toxicol Appl Pharmacol. 1995; 131:244-252.

33) Sutton KA, Maiti S, Tribley WA, Lindsey JS, Meistrich ML, Bucana CD, Sanborn BM, Joseph DR, Griswold MD, Cornwall GA and Wilkinson MF. Androgen regulation of the Pem homeodomain gene in mice and rat Sertoli and epididymal cells. J Androl 1998; 19:21-30.

34) Klaunig JE, Babich MA, Baetcke KP, Cook JC, Corton JC, David RM, DeLuca JG, Lai DY, McKee RH, Peters JM, Roberts RA and Fenner-Crisp PA: PPAR $\alpha$ agonist-induced rodent tumors: modes of action and human relevance. Crit Rev Toxicol 2003; 33:655780 .

35) Sano Y, Nakashima H, Yoshioka N, Ethp N, Nomiyama T, Nishiwaki Y, Takebayashi T and Oame K. Trichloroethylene liver toxicity in mouse and rats: microarray analysis reveals species differences in gene expression. Arch Toxicol 2009; 83:835-849.

36) Delbès G, Duquenne C, Szenker J, Taccoen J, Habert R and Levacher C. Development changes in testicular sensitivity to estrogens throughout fetal and neonatal life. Toxicol Sci 2007; 99:234-243

37) França LR, Ogawa T, Avarbock MR, Brinster RL and Russell LD. Germ cell genotype controls cell cycle during spermatogenesis in the rat. Biol Reprod 1998; 59:1371-1377.

38) Clermont Y and Harvey SC. Duration of the cycle of the seminiferous epithelium of normal, hypophysectomized and hypophysectomized hormone treated albino rats. Endocrinology 1965; 76:80 -89 .

39) Clermont $Y$ and Trott M. Duration of the cycle of the seminiferous epithelium in the mouse and hamster determined by means of $3 \mathrm{H}$-thymidine and redioautography. Fertil Steril 1969; 20:805817.

40) Thomas JA and Northup SJ. Toxicity and metabolism of monoethylhexyl phthalate and di-ethylhexyl phthalate: a survey of recent 
literature. J Toxicol Environ Health 1982; 9:141-152.

41) Richburg JH and Boekelheide K. Mono-(2-ethylhexyl) phthalate rapidly alter both Sertoli cell vimentin filaments and germ cell apoptosis in young rat testes. Toxicol Appl Pharmacol 1996; 137: $2-50$.

42) Tirado OM, Selva DM, Toràn N, Suárez-Quian CA, Jansen M, Mcdonnell DP, Reventós J and Munell F. Increased expression of estrogen receptor $\beta$ in pachytene spermatocytes after short-term methoxyacetic acid administration. J Androl 2004; 25:84-94.

43) Xiong Q, Xie P, Li H, Hao L, Li G, Qiu T and Liu Y. Involvement of Fas/FasL system in apoptotic signaling in testicular germ cell of male Wistar rats injected i.v. with microcystins. Toxicon 2009;
54:1-7.

44) Zhang X, Chen FH and Huang Z. Apoptosis induced by acrylamide is suppressed in a $21.5 \%$ fat diet through caspase-3independent pathway in mice testis. Toxicol Mech Methods 2009; 19:219-224.

45) Boekelheide K. Sertoli cell toxicants. In. The Sertoli Cell (L. D. Russell and M. D. Griswold, eds.), 1993; pp. 551-575. Cache River Press, Clearwater, FL.

46) Kopecky M, Semecky V and Nachtigal P: Vimentin expression during altered spermatogenesis in rats. Acta Histochemica 2005; 107:279-289. 